\title{
A Himalayan Keystone Species: The Snow Leopard
}

\author{
Dev Sajnani \\ Neerja Modi School \\ DOI: 10.29322/IJSRP.11.11.2021.p11921 \\ http://dx.doi.org/10.29322/IJSRP.11.11.2021.p11921
}

\begin{abstract}
Biodiversity, the variety and variability of plant and animal species, is the basis for the survival of entire communities, especially those dependent on ecological life support from specific plants, animals or entire ecosystems. However, as society progresses, the need for sustenance and management of biodiversity also increases. This study focuses on the conservation of the Snow Leopard (Panthera uncia), a species native to the mountain ranges of Central and South Asia. The paper documents the ecology and habitat of the snow leopard, the threats they face classified into four categories, and examines policies currently in place while also suggesting new implementations to tackle the loss of the species.
\end{abstract}

Index Terms- Biodiversity, Conservation, Snow Leopard

\section{INTRODUCTION}

The snow leopard (Panthera Uncia) is an endemic species of Central and South Asia that now has numbers of less than 10,000 individuals[20]. Belonging to a habitat above the treeline, in harsh environments, leaves the species little option for availability of food and habitat. The impact of climate change and rising treelines have led to habitat becoming scarce, where more than one individual might be in the same range.

It's main prey include the blue sheep (Pseudois nayaur), siberian ibex(Capra sibirica), Argali (Ovis ammon), and Markhor(Capra falconeri)[12], along with a few other plants and some vegetation. But growing competition against species such as wolves and feral dogs leaves them little choice but to prey on cattle and domesticated livestock due to a lack of food, pitting them against humans, who might face severe economic losses due to this, and, thus, result in retaliatory killing of the snow leopard. In addition to all of this, populations in the mountain regions of India are continually growing which naturally leads to economic impacts such as building of infrastructure and removal of forests. This economic development has adverse impacts on the wildlife species which indirectly negatively impacts the snow leopard.

In addition, there has been an acknowledgement of new threats such as mining and large-scale infrastructure projects like dams, roads and railways.

Conservation efforts have seen some high investment in establishing Protected Areas(PAs) for conserving the species, increasing awareness about the species and its advantages, incentivising people, and protecting the species from poaching and conflicts against local communities among other methods [25, 20, 17]. But these have shown to have little effect.

\section{METHOD}

Aim- The aim of this paper is to study the habitat of the snow leopard to analyze threats on the population and the impact on the ecology of the surrounding area. The paper tries to evaluate conservation policies currently in place by the government and provides additional potential solutions for the conservation of the species.

\section{Objectives-}

1. To examine the habitat of the snow leopard.

2. To explore the various threats faced by the snow leopard and their impacts.

3. To evaluate current policies in place to conserve the species and suggest additional policies.

\section{RESULTS AND DISCUSSION}

This section has been divided into 3 parts pertaining to the objectives of this paper. First, it gives a general review of the habitat a snow leopard lives in; after that, it looks at the threats snow leopards might face and the effects these threats might have on the population of the snow leopard and on the ecology of the surrounding area; lastly, it suggests policies to conserve the species. 


\section{A. Habitat of a Snow Leopard}

Snow leopards generally occur between elevations of 3,000-4,500 m, within subalpine and alpine zones above the treeline[25]. Snow Leopards are known to show a strong preference for steep terrain and irregular slopes along which they traverse across their home ranges. They also prefer to migrate to lower elevations in winter to avoid getting grounded by the snow layers, and even to follow the tracks of their prey [14].

They are exclusively found in the mountain regions of Central Asia, namely China, India, Pakistan, Bhutan, Nepal, Afghanistan, Tajikistan, Uzbekistan, Kazakhstan, Kyrgyzstan, Mongolia and Russia[20].

However, looking at all of aforementioned habitats is beyond the scope of this paper. I am going to specifically focus on the habitat in India, present in the Himalayan mountain ranges. The geographical range of snow leopards spans a large part of the western Himalayan ranges, being Jammu and Kashmir, Himachal Pradesh and Uttarakhand. Snow leopards are also found in the eastern Himalayan ranges, covering Sikkim and Arunachal Pradesh.

The total range of snow leopard presence in India is estimated to be around $126,842 \mathrm{~km}^{2}$, with approximately $119,715 \mathrm{~km}^{2}$ in the western range and $7,127 \mathrm{~km}^{2}$ in the eastern range. The total population is estimated to be $400-700$ snow leopards, found primarily above $3,200 \mathrm{~m}$ in the west and 4,200m in the east. in decreasing density as we move from the north western areas of Jammu and Kashmir to the southern ranges[8].

\section{Territory}

Snow leopards mark their home ranges mainly with scrapes on the ground and scent marks on overhanging cliffs and boulders [23, 1], favoring locations along ridgelines, gorges, stream junctions and valley bottoms [7]. Since the presence of marks increases during mating season, it is assumed that these markings are used to communicate the presence of an individual and maybe even reproductive condition $[13,1]$.

\section{Home Range}

Snow leopards require large spatial regions, oftentimes leading to overlaps in home ranges. A study in Nepal showed that home ranges varied between 12 to $39 \mathrm{~km}^{2}$ with substantial overlap between individuals. Home ranges of snow leopards have been reported to be very different for the various countries. In Mongolia, for example, home ranges were reported to be greater than $400 \mathrm{~km}^{2}$, often being greater than $1,000 \mathrm{~km}^{2}$. Research in Spiti Valley in Himachal Pradesh, using intensive camera trapping across $4,000 \mathrm{~km}^{2}$, showed an average home range size of $130 \mathrm{~km}^{2}$. Individual snow leopards have generally been reported to cover between 1 to $2 \mathrm{~km}$ every day, however, occasionally they might undertake long-distance journeys of over $20 \mathrm{~km}$ in a single day. Research also suggests that snow leopards remain within limited ranges for about a week or 10 days before shifting their activity to another section within their home range. It is believed that this is done in response to the availability of wild prey species. Several studies hint that marking has an important role in separating individuals, as snow leopards have been seen to mark their core areas significantly more than other areas within the home range.

\section{Climate}

Plants and vegetation are scarce in snow leopard habitats owing to the below freezing temperature level, with only infrequent shrubs and grass. The average temperature per year is around $8^{\circ}$ Celsius, with an average of $13^{\circ} \mathrm{Celsius}$ in the summer.

Although this might not sound too cold, temperatures change rapidly. The winter average temperature of $0.5^{\circ}$ Celsius can see lows down to $-10^{\circ} \mathrm{C}$ in January.

Average precipitation in snow leopard habitats is near 16 inches, with just 3 inches and 0.5 inches of precipitation in summer and winter respectively. Sleet, snow, and rain are the forms of precipitation that fall in the Himalayan Alpine.

\section{B. Threats to the species}

The Snow Leopard Survival Strategy (SLSS) was developed to identify the key threats faced by snow leopards and create a documentation on all current knowledge regarding the survival, population, distribution and ecology of the snow leopard, while also identifying key areas that need more research, all to set a list of priorities for snow leopard conservation.

The SLSS threat analysis groups a list of 32 threats into 4 major categories: Habitat and Prey, Direct Killing; Policy and Awareness; and Other Issues.

Each threat has been analyzed based on area, intensity, and urgency using a scale of 1-5 for each, where 1 indicates a low threat and 5 a serious threat. The total score range is from Low(1-5),Medium(6-10) to High(11-15). A list of all 32 threats and their respective scores for India and mean scores for all countries can be found in the appendix. 
I will be focusing on the threats which were ranked high for India by dividing them into categories: Habitat and Movement, Ecological Factors, Policy and Awareness, and Human Interference.

\section{Habitat and Movement}

The threats I am considering here are habitat degradation, climate change and restriction of movement due to fencing. The habitat degradation score for India was 10 , almost reaching the scale of high. For fencing, even though the scale was 8 , being right in the middle, it is considerably higher than the mean score of 3.6. The climate change score was also 10 which is concerning; all three of these are threats to not only the snow leopard population but also all other species in the area. Snow leopards require a high spatial range, even though young individuals manage to survive with overlapping, so fencing to limit movement not only poses the threat of conflict between dominant snow leopards but also reduces prey availability since, as mentioned earlier, snow leopards shift their core activity location around every week in response to prey availability.

Global trends about climate change include rising mean temperature levels, irregular precipitation levels and season cycles. Assessments by the Intergovernmental Panel on Climate Change(IPCC) in 2007 and the International Centre for Integrated Mountain Development(ICIMOD) in 2009 suggest that mountain areas in Asia are more vulnerable to the impacts of climate change, such as increased frequency of extreme weather events, unpredictable precipitation and prolonged conditions such as floods or droughts. Reference [29] reported the possible consequences climate change in the greater Himalayan region can have: melting permafrost, faster glacial retreat and extreme weather can have impacts on various fronts such as ecosystems, agriculture, fresh water, human health, and even economic perspectives such as infrastructure and tourism. Global warming is believed to affect livestock grazing patterns and human land use, which in turn will impact snow leopards and their prey. Stocking densities can be expected to increase if pasture productivity increases, whereas reduced pasture productivity and/or fresh water availability may push livestock numbers down or lead to abandonment of some mountain pastures. The finescale effects of climate change at particular sites, though, are harder to predict. According to a recent study assessing snow leopard habitat in the Himalayas, it is projected that snow leopard habitat will decline by $30 \%$ over the next century as a result of an upward shift in tree line and shrinkage of alpine habitat [6]. Tree growth may, however, be slowed or prevented by livestock grazing or cutting by local people.

Today, the remaining natural habitat in the Himalayas is patchy. The steadily increasing population in the hotspot has led to extensive clearing of forests and grasslands for cultivation, and widespread logging. Both legal and illegal logging often occurs on extremely steep slopes, resulting in severe erosion. The conversion of forests and grasslands for agriculture and settlements has led to large-scale deforestation and habitat fragmentation. Large areas of remaining habitat in the hotspot are highly degraded. Overgrazing by domestic livestock, including cattle and domesticated yak, is widespread in the lowlands and alpine ecosystems. The flora of fragile alpine meadows has been overexploited for traditional medicine (because medicinal plant collectors invariably uproot the entire plant, regrowth is hampered).

Fuelwood collection and non-timber forest product extraction, both for domestic consumption and export, has inflicted severe damage to some forest ecosystems. Unplanned and poorly managed tourism has led to environmental deterioration. Political unrest, often in the form of insurgencies, also threatens the integrity of some protected areas.

\section{Ecological Factors}

This includes factors related to the ecology of the area such as prey availability, competition for prey, and disease. With scores of each being at least an 8 , competition with feral dogs being at 11 , exceptionally higher than the mean score of 4.2 , all these issues require specific attention.

Although rated low overall, disease does pose a significant threat to the snow leopard population of India. Zoo animals are reported to be infected with common feline viruses (FIV or Immunodeficiency Virus Infection) and suffer excessive neurodegenerative disorders and ocular colobomas. Moreover, scabies mange outbreaks caused by mites on blue sheep and other prey animals have been reported, associated with significant mortality in some cases [5]. This is because infectious diseases from livestock can pass on to predators, essentially putting them at risk too.

Snow leopards are also endangered by declines in the availability of their main prey species. These declines, in part, are impacting their interaction with humans. This is because as wild prey availability decreases, snow leopards are more likely to attack livestock cattle such as sheep, goats and even horses, which might lead to conflicts. This is described in more detail in the Human Interference section. What we do know is that conservation of wild prey species is of utmost importance for snow leopard conservation. Some primary large prey species are at risk due to large-scale poaching, competition for fodder due to 
increasing livestock populations, habitat degradation, and, in some cases, even transfer of contagious diseases[14, 2, 19, 4]. Feral dogs pose a major threat to the snow leopard population in the Himalayas. Although this problem is not significant in other snow leopard habitats, in India, rapid growth in population and expansion of pasture land for agriculture moving the tree-line upwards have all led to a greater population in these sparsely populated areas, leading to a high increase in the number of domestic animals. Because ownership laws in India are quite loose, this allows many to use their dogs as a means of depredation putting prey availability for the snow leopard at risk, as feral dogs are seen consuming the same prey as a snow leopard [22]. They are also known as vectors of various diseases such as canine parvovirus(CPV), canine hepatitis $(\mathrm{CH})$, canine distemper virus(CDV), and rabies [15, 3]. A survey conducted in Spiti Valley [9] showed that a high proportion of the dog population had previous exposure to $\mathrm{CPV}$ and $\mathrm{CH}$ while a low proportion had exposure to CDV. In addition, it has been found that feral dogs kill more livestock in Spiti Valley than both snow leopard and the himalayan wolf [27].

\section{Policy and Awareness}

It is quite clear that policy and awareness issues are the most necessary when building conservation plans for any species of flora or fauna. This fact is highlighted considerably when policy issues almost all rank at 12 for India.

Snow leopards, their prey, and habitat are very important and undervalued. There is insufficient understanding, awareness, and concern regarding the ongoing degradation of ecosystems. This applies to people at all levels of society within and outside the snow leopard range, from general society to local and national government leaders. The snow leopard remains a less well-known species than other charismatic species, such as tigers and elephants; it has, thus, gotten less funding for conservation. In addition, many Indians, especially those living along the specie's range, have a negative view of them. Although the situation is changing a bit, all countries within the snow leopard range report that they are lacking in trained conservation practitioners. This includes everyone from frontline PA staff, to wildlife managers, to law enforcement officers, to scientists. A lack of funds limits their effectiveness, especially in cases in which conservation staff levels are adequate, like some scientific institutions. Specifically, range countries lack trained personnel to respond to community needs and develop community programs.

Several countries are weak when it comes to conservation-related policies, laws, and institutions. The reason for this is largely due to insufficient funding for snow leopard conservation and conservation in general, mostly because the range countries are developing and some are exceedingly poor [17]. It is generally not possible to scale up successful practices with donor funding. International support is, thus, needed by most of the range countries for successful snow leopard conservation. There is also a need for the establishment of newer, large-scale Protected Areas since current PAs are quite small relative to the snow leopard ranges. This is essential in order to reduce hunting pressure on ungulate species and to protect their habitats. However, establishment of new PAs is often met with strong political resistance, as it is expensive due to the high cost of enforcing boundaries; in addition, it can cause conflicts with local rural communities due to the inception of new rules and restrictions over the use of resources [28]. Even in PAs with formally regulated land-use, livestock grazing is rarely restricted effectively. Both areas suffer from a lack of political support and human and financial investment leading to lax regulations and inefficient conservation. With growing populations of humans and livestock in mountain regions, it is becoming increasingly difficult to maintain strict protected areas, with some even under pressure to be converted to other land uses.

Enforcement of hunting bans or hunting limitations is often difficult for the same reasons as the enforcement of PA regulations. The involvement of the military and border guards in the region does not help. Poaching by military personnel is also a problem, as denoted in the table. Thus, hunting bans do not necessarily protect local ungulate populations from serious decline and extinction, unless these bans can be effectively executed and monitored, something that is almost impossible in the Himalayan region due to constant transnational conflicts.

\section{Human Interference}

Although the areas within snow leopard ranges are sparsely populated, more people are continually inhabiting them. Most of these people depend on traditional livestock herding for self-sustenance. This has led to overgrazing in various ranges and has caused the habitat to become fragmented. In addition, most of the land used for grazing is now unsuitable even for agriculture due to erosion. This just goes on to show the impact a small community of people can have. Human interference issues are not limited to this.

Wild prey availability has gone down due to competition with domestic livestock for fodder. Reference [26] indicated that 
graminoid was the blue sheep's primary winter diet, but is reducing due to livestock grazing; Reference [2] showed depletion of blue sheep in areas of high livestock density on account of competition for fodder. Reference [21] found that livestock competed with Mongolian pikas (Ochotona pallasi), while Reference [2] found that sheep and goat frequently exclude ibex by blocking access to pastures if flocks are accompanied by shepherds and their dogs. Because most herders practice agropastoralism, overgrazing has led to a decrease in wild prey and an increase in the presence of domestic livestock. Feral dogs are also used to prevent depredation, essentially reducing fodder available for wild species even more. As mentioned under ecological issues, feral dogs also feed on the same prey as snow leopards. Because population densities of the snow leopard's main prey have decreased, there has been an increase in the number of attacks snow leopards cause on domestic cattle. This has caused an increase in retaliation killing by members of those communities. A situation of low food availability and threat from local communities has forced snow leopards to displace to even higher ranges, thus decreasing available habitat range. There have also been cases when snow leopards were not to blame, as wolves often prey on the same livestock [11, 18, 24]. It went as far as herders entering a den to kill two cubs in 2016 [28].

As specified earlier, transnational cooperation is imperative especially in the case of India. This is not only for the establishment of mutually agreed protected areas, but even to protect habitats from conflicts. Large scale conflicts can lead to land deformation and fragmentation.

Another issue that is largely not accounted for is development in the area. An increase in the population has naturally led to an increase in the requirement of facilities such as roads and railways, development projects, and infrastructure for employment. Such investments attract even more people and lead to a cycle. The large increase in population due to this has caused a greater part of snow leopard ranges to overlap with agro-pastoral land. Moreover, the lack of compensation herders get after suffering losses has led to essentially no decrease in retaliatory killing[10].

\section{Snow Leopard Conservation}

We know that the snow leopard population is one of the most sensitive species right now due to the lesser availability of wild prey for food, competition against other species and retaliatory killing by humans.

This section will analyse current policies in place to conserve the snow leopard and suggest additional policy solutions.

\section{Design of Incentive Programs}

Keeping in mind the high proportion of livestock predation that takes place, and the retaliatory killing that results from that predation, there needs to be a way for pastoralists and the carnivore population to co-exist. Thus, protecting the economic sources of herders should be effective to some extent in decreasing retaliatory killing.

One such incentive program is the Snow Leopard Enterprise(SLE) in Mongolia, which works with families living in the snow leopard habitat to change perspectives about the snow leopard. They encourage sustainable economic opportunities among women of the region, like handcrafting ornaments using raw material, rather than selling the material as a whole.The program has been successful in increasing annual incomes of households by 4\% [17], which might not seem much, but these households get a $20 \%$ cash bonus if no hunting takes place in the area, making them much more willing to actively conserve the species.

However, compensation based programs such as this have proved inadequate[17].

Livestock insurance schemes have also been launched in a few communities, like Pakistan. This scheme provides herders with monetary incentives to protect their local environment and not partake in retaliatory killings in case of livestock predation [28]. The shortcoming of this scheme is the acquisition of adequate funding, as asking herders for a premium is going to reduce the incentive it provides.

However, what this demonstrates is that there is an active need of community-inclusive incentive programs that can promote cohabitation, and maybe even mutual benefit arising from ecotourism or sustainable microproduction.

\section{Education}

This is probably the most effective way of conserving all species. Educational programs can teach the people living in these areas a lot of things ranging from economic benefits to appropriate perspectives.

Because most people here live in low-income households who depend on agriculture and livestock husbandry for sustenance, there is a need to teach effective management. A lot of times there can be substantial loss to livestock if a snow leopard breaks into a corral. Herders generally build low-quality corrals, often without roofs and with gaps in walls [28]. Effective corral development can be useful in protecting livestock from predators, even those other than the snow leopard. However, 
building these corrals is often expensive and current corrals are the work of government and conservation organisations; there is an additional need of funding, both for educating herders about effective husbandry and building these corrals [16].

\section{CONCLUSION}

Even though it has been titled an 'endangered species', we find that we do not really know much about the snow leopard; this is mainly due to 3 reasons:1) its elusive nature; 2) inaccessibility to its habitat; 3) difficulty in quantifying emerging threats.

The above mentioned solutions can work to some extent in assisting snow leopard conservation, but can in no way guarantee conservation. Significant economic analysis is required on the damages snow leopards cause to agro-pastoralists, on their movement, and on their prey habits to reach a framework that combines elements of the aforementioned solutions with other approaches that also take into account political unrest and climate challenges.

\section{APPENDIX}

Threats table as per Global Snow Leopard and Ecosystem Protection Program(GSLEP) process.

\begin{tabular}{|c|c|c|}
\hline Threats & India & Mean Score \\
\hline \multicolumn{3}{|c|}{ Habitat and Prey } \\
\hline Habitat Degradation & 10 & 8.2 \\
\hline Habitat Fragmentation & 6 & 6.3 \\
\hline $\begin{array}{l}\text { Prey Reduction due to Illegal } \\
\text { Hunting }\end{array}$ & 6 & 11.0 \\
\hline $\begin{array}{l}\text { Prey Reduction due to competition } \\
\text { with livestock }\end{array}$ & 8 & 10.7 \\
\hline Prey reduction due to legal hunting & 0 & 3.0 \\
\hline Prey Reduction due to Disease & 8 & 5.7 \\
\hline $\begin{array}{l}\text { Fencing that disrupts } \\
\text { movements/migration }\end{array}$ & 8 & 3.6 \\
\hline \multicolumn{3}{|c|}{ Direct Killing or Removal of Snow Leopards } \\
\hline $\begin{array}{l}\text { In retribution for livestock } \\
\text { depredation }\end{array}$ & 8 & 9.7 \\
\hline Poaching for trade in hides or bones & 6 & 9.3 \\
\hline $\begin{array}{l}\text { Zoo and Museum Collection of } \\
\text { Live animals }\end{array}$ & 0 & 1.1 \\
\hline $\begin{array}{l}\text { Traditional Hunting of Snow } \\
\text { Leopards }\end{array}$ & 0 & 2.4 \\
\hline $\begin{array}{l}\text { Secondary Poisoning and Trapping } \\
\text { of Snow Leopards }\end{array}$ & 6 & 6.7 \\
\hline
\end{tabular}




\begin{tabular}{|c|c|c|}
\hline Diseases of Snow Leopards & 8 & 4.3 \\
\hline $\begin{array}{l}\text { Potential Legal Hunting of Snow } \\
\text { Leopards }\end{array}$ & 0 & 1.4 \\
\hline \multicolumn{3}{|c|}{ Policy and Awareness } \\
\hline Lack of Appropriate Policy & 10 & 9.2 \\
\hline Lack of Effective Enforcement & 12 & 11.8 \\
\hline Lack of Transboundary Cooperation & 8 & 9.1 \\
\hline Lack of Institutional Capacity & 12 & 10.7 \\
\hline $\begin{array}{l}\text { Lack of Awareness among local } \\
\text { people }\end{array}$ & 12 & 10.8 \\
\hline $\begin{array}{l}\text { Lack of Awareness among policy } \\
\text { makers }\end{array}$ & 12 & 10.1 \\
\hline \multicolumn{3}{|c|}{ Other Issues } \\
\hline War and related military Activity & 9 & 3.8 \\
\hline $\begin{array}{l}\text { Human Population } \\
\text { Growth(rapid)/Poverty }\end{array}$ & 7 & 7.0 \\
\hline $\begin{array}{l}\text { Feral Dogs Attacking Snow } \\
\text { leopards and Prey }\end{array}$ & 11 & 4.2 \\
\hline $\begin{array}{l}\text { Poaching and Wildlife trade by } \\
\text { migrant workers }\end{array}$ & 10 & 5.0 \\
\hline Poaching by military personnel & 7 & 7.2 \\
\hline \multicolumn{3}{|c|}{ Emerging Threats } \\
\hline Climate Change & 10 & 9.8 \\
\hline $\begin{array}{l}\text { Growing Livestock populations and } \\
\text { intensifying human-wildlife conflict }\end{array}$ & 10 & 12.1 \\
\hline Large-scale development projects & 10 & 6.8 \\
\hline $\begin{array}{l}\text { Impacts due to mineral } \\
\text { exploration/mining(local) }\end{array}$ & 7 & 6.8 \\
\hline $\begin{array}{l}\text { Impacts due to hydroelectric } \\
\text { projects }\end{array}$ & 5 & 4.7 \\
\hline Impacts due to roads or railroads & 11 & 5.7 \\
\hline
\end{tabular}




\begin{tabular}{|l|l|l|}
\hline $\begin{array}{l}\text { Disturbance related to } \\
\text { cordyceps collection }\end{array}$ & 7 & 3.4 \\
\hline
\end{tabular}

\section{REFERENCES}

[1] Ahlborn, G. G., and Jackson, R. (1988). Observations on the ecology of snow leopard in west Nepal. Pages 65-87 In: H. Freeman, (Ed). Proceedings of the Fifth International Snow Leopard Symposium. International Snow Leopard Trust and Wildlife Institute of India, Seattle.

[2] Bagchi, S., Mishra, C. and Bhatnagar, Y.V. (2004). Conflicts between traditional pastoralism and conservation of Himalayan ibex (Capra sibirica) in the Trans-Himalayan Mountains. Animal Conservation, 7, 121-128.

[3] Belsare, A. V., Vanak, A. T., \& Gompper, M. E. (2014). Epidemiology of viral pathogens of free-ranging dogs and Indian foxes in a human-dominated landscape in central India. Transboundary and Emerging Diseases, 61, 78-86. https://doi.org/10.1111/tbed.12265

[4] Berger, J., Buuveibaatar, B. and Mishra, C. (2013). Globalization of the cashmere market and the decline of large mammals in Central Asia. Conservation Biology, 27, 679-689.

[5] Dagleish et al. (2007). Fatal Sarcoptes scabiei infection of blue sheep (Pseudois nayaur) in Pakistan.Journal of Wildlife Diseases, 43(3), 512-7.

[6] Forrest, J. L., Wikramanayake, E., Shrestha, R., Areendran, G., Gyeltshen, K., Maheshwari, A., Mazumdar, S., Naidoo, R., Thapa, G. J., \& Thapa, K. (2012). Conservation and climate change: Assessing the vulnerability of snow leopard habitat to treeline shift in the Himalaya. Biological Conservation, 150(1), 129-135. https://doi.org/10.1016/j.biocon.2012.03.001

[7] Fox, J. L., \& Chundawat, R. S. (2016). What is a Snow Leopard? Behavior and Ecology. In Snow Leopards (pp. 13-21). Elsevier. http://dx.doi.org/10.1016/b978-0-12-802213-9.00002-x

[8] Fox, J. L., Sinha, S. P., Chundawat, R. S., \& Das, P. K. (1991). Status of the snow leopard Panthera uncia in Northwest India. Biological Conservation, 55(3), 283-298. https://doi.org/10.1016/0006-3207(91)90033-6

[9] Home, C., Pal, R., Sharma, R. K., Suryawanshi, K. R., Bhatnagar, Y. V., \& Vanak, A. T. (2017). Commensal in conflict: Livestock depredation patterns by free-ranging domestic dogs in the Upper Spiti Landscape, Himachal Pradesh, India. Ambio, 46(6), 655-666. https://doi.org/10.1007/s13280-016-0858-6

[10] Ikeda, N. (2004). Economic impacts of livestock depredation by snow leopard Uncia uncia in the Kanchenjunga Conservation Area, Nepal Himalaya. Environmental Conservation, 31(4), 322-330. https://doi.org/10.1017/s037689290400177

[11] Jackson, Rodney and Hunter, Don O. 1996 (Second Edition). Snow Leopard Survey and Conservation Handbook. International Snow Leopard Trust, Seattle, Washington and U.S. Geological Survey, Fort Collins Science Center, Colorado. 154 pages + appendices.

[12] Lyngdoh, S., Shrotriya, S., Goyal, S. P., Clements, H., Hayward, M. W., \& Habib, B. (2014). Prey Preferences of the Snow Leopard (Panthera uncia): Regional Diet Specificity Holds Global Significance for Conservation. PLoS ONE, 9(2), e88349. https://doi.org/10.1371/journal.pone.0088349

[13] Mallon, D.P. (1991). Status and conservation of large mammals in Ladakh. Biological Conservation, 56, 101-119.

[14] McCarthy, T.M. and Chapron, G. (2003) Snow Leopard Survival Strategy. ISLT and SLN, Seattle, USA.

[15] Menezes, R. (2008). Rabies in India. Canadian Medical Association Journal, 178(5), 564-566. https://doi.org/10.1503/cmaj.071488

[16] Mohammad, G., Mostafawi, S. N., Dadul, J., \& Dadul, J. (2016). Corral Improvements. In Snow Leopards (pp. 180-183). Academic Press

[17] Nyhus, P., McCarthy, T., \& Mallon, D. (2016). Snow leopards: Biospanersity of the world: Conservation from genes to landscapes. Academic Press.

[18] Oli, M. K., Taylor, I. R., \& Rogers, D. M. E. (1993). Diet of the snow leopard (Panthera uncia) in the Annapurna Conservation Area, Nepal. Journal of Zoology, 231(3), 365-370. https://doi.org/10.1111/j.1469-7998.1993.tb01924.x

[19] Ostrowski, S., \& Gilbert, M. (2016). Diseases of free-ranging snow leopards and primary prey species. In Snow Leopards (pp. 97-112). Elsevier. http://dx.doi.org/10.1016/b978-0-12-802213-9.00009-2

[20] Panthera uncia: McCarthy, T., Mallon, D., Jackson, R., Zahler, P. \& McCarthy, K. (2016). IUCN Red List of Threatened Species. https://doi.org/10.2305/iucn.uk.2017-2.rlts.t22732a50664030.en

[21] Retzer, V. (2007). Forage competition between livestock and Mongolian Pika (Ochotona pallasi) in Southern Mongolian mountain steppes. Basic and Applied Ecology, 8(2), 147-157. https://doi.org/10.1016/j.baae.2006.05.002

[22] Ritchie, E. G., Dickman, C. R., Letnic, M., \& Vanak, A. T. (2013). Dogs as predators and trophic regulators. In Free-Ranging Dogs and Wildlife Conservation (pp. 55-68). Oxford University Press. http://dx.doi.org/10.1093/acprof:osobl/9780199663217.003.0002

[23] Schaller, G.B. (1977). Mountain Monarchs: Wild Sheep and Goats of the Himalaya. University Chicago Press, Chicago

[24] Shehzad, W., McCarthy, T. M., Pompanon, F., Purevjav, L., Coissac, E., Riaz, T., \& Taberlet, P. (2012). Prey Preference of Snow Leopard (Panthera uncia) in South Gobi, Mongolia. PLoS ONE, 7(2), e32104. https://doi.org/10.1371/journal.pone.0032104

[25] Snow Leopard Network (2014). Snow Leopard Survival Strategy. Revised 2014 Version Snow Leopard Network, Seattle, Washington, USA.

[26] Suryawanshi K.R., Bhatnagar, YV. and Mishra, C. (2009). Why should a grazer browse? Livestock impact on winter resource use by bharal (Pseudois nayaur). Oecologia DOI 10.1007/s00442-009-1467- x

[27] Suryawanshi, K. R., Bhatnagar, Y. V., Redpath, S., \& Mishra, C. (2013). People, predators and perceptions: Patterns of livestock depredation by snow leopards and wolves. Journal of Applied Ecology, 50(3), 550-560. https://doi.org/10.1111/1365-2664.12061

[28] Theile, S. (2003). Fading footprints: The killing and trade of snow leopards.

[29] Xu, J., Grumbine, R. E., Shrestha, A., Eriksson, M., Yang, X., Wang, Y., \& Wilkes, A. (2009). The Melting Himalayas: Cascading effects of climate change on water, biospanersity, and livelihoods. Conservation Biology, 23(3), 520-530. https://doi.org/10.1111/j.1523-1739.2009.01237.

Author - Dev Sajnani, Neerja Modi School, sajnanidev2004@gmail.com 